Copyright(C)2009. The Korean Academy of Tuberculosis and Respiratory Diseases. All rights reserved.

\title{
Association of Diabetes Mellitus and Metabolic Syndrome with Idiopathic Pulmonary Fibrosis
}

Division of Pulmonology, Department of Internal Medicine, ${ }^{1}$ Gachon University Gil Hospital, Incheon, ${ }^{2}$ Sungkyunkwan University Samsung Medical Center, College of Medicine, Seoul, Korea

Yu Jin Kim, M.D. ${ }^{1}$, Jeong-Woong Park, M.D. ${ }^{1}$, Sun Young Kyung, M.D. ${ }^{1}$, Chang Hyeok An, M.D. ${ }^{1}$, Sang Pyo Lee, M.D. ${ }^{1}$, Hye Yun Park, M.D. ${ }^{2}$, Man Pyo Chung, M.D. ${ }^{2}$, Sung Hwan Jeong, M.D. ${ }^{1}$

\section{폐섬유화증과 당뇨와 대사 증후군의 연관성 연구}

\section{김유진 ${ }^{1}$, 박정웅 ${ }^{1}$ 경선영 ${ }^{1}$, 안창혁 ${ }^{1}$ 이상표 ${ }^{1}$, 박혜윤 $^{2}$, 정만표 ${ }^{2}$, 정성환 $^{1}$}

${ }^{1}$ 가천의대길병원 호흡기내과, ${ }^{2}$ 성균관대학교 의과대학 내과학교실 삼성서울병원 호흡기내과

Background: Reactive oxygen species (ROS) by oxidative stress may play an important role in the pathogenesis of various chronic diseases such as diabetes mellitus, obesity, hyperlipidemia, hypertension and malignancy that are linked to metabolic syndrome. Oxidative stress has been implicated in the pathogenesis of idiopathic pulmonary fibrosis (IPF). We examined the relationship between IPF and presenting factors associated with metabolic disorders.

Methods: One hundred fourteen patients who met the current consensus of IPF definition were enrolled from March 2000 to April 2006 in Gil Hospital and Samsung Medical Center in Korea. One hundred thirty-four control subjects without pulmonary diseases were selected from subjects who visited Gil hospital for routine medical examinations, including low-dose chest computed tomography from January 2002 to July 2006. Retrospectively, we analyzed the clinical characteristics, the results of blood examinations, and lung function tests from medical records of both groups.

Results: IPF patients and control subjects differed in the prevalence of diabetes mellitus as assessed by univariate analysis. Multivariate analysis demonstrated that diabetes mellitus and obesity were associated with IPF. The adjusted odds ratios for diabetes mellitus were 2.733 (95\% confidence interval [CI], 1.282 5.827) and 2.001 (95\% [CI], 1.063 3.766) for obesity. The remaining factors tested showed no differences between the patient group and the control.

Conclusion: Diabetes mellitus and obesity may be associated with IPF development.

Key Words: Diabetes mellitus, Idiopathic pulmonary fibrosis, Metabolic syndrome, Oxidative stress

\section{Introduction}

Idiopathic pulmonary fibrosis (IPF) is characterized by irreversible, heterogenous inflammation and fibrosis

Address for correspondence: Sung Hwan Jeong, M.D. Division of Pulmonology, Department of Internal Medicine, Gachon University Gil Medical Center, 1198, Guwol 1-dong, Namdong-gu, Incheon 405-760, Korea

Phone: 82-32-460-3200, Fax: 82-32-469-4320

E-mail: jsw@gilhospital.com

Received: May. 29, 2009

Accepted: Jul. 13, 2009 of lung parenchyma. It is an age-related, chronic, and fatal disease. Various epidemiologic studies had reported risk factors of IPF, including wood dust, metal dust, cigarette smoking, gastroesophageal reflux, viruses such as adenovirus, cytomegalovirus, hepatitis C, Epstein-Barr virus (EBV), Herpes virus and some metabolic diseases $^{1-4}$. Recently, It is widely accepted that oxidative stress, generated by imbalance between oxidants and antioxidants, may be associated with $\mathrm{IPF}^{1}$. Oxidative stress may affect on epithelial layer, growth factors, in- 
flammatory cells, proteases, proteases inhibitors, and the extracellular matrix and initiate to develop end-stage fibrosis of major organs ${ }^{5-7}$. Other investigators suggested that reactive oxygen species (ROS) by oxidative stress may play an important role in the pathogenesis of various chronic diseases such as diabetes mellitus (DM), obesity, hyperlipidemia, and hypertension that are linked to metabolic syndrome ${ }^{8-10}$. Recent report suggested the association of DM with $\mathrm{IPF}^{4}$. We performed the present study, using a case-control approach, to determine whether other metabolic disorders may be relevant to development of IPF.

\section{Materials and Methods}

\section{Study design}

IPF patients were admitted to Gachon University Gil Hospital and Sungkyunkwan University Samsung Medical Center from 1 March 2000 to 30 April 2006. IPF was diagnosed by respiratory specialist based on clinical history, clinical examination, high resolution CT (HRCT). Fiberoptic bronchoscopy with bronchoalveolar lavage (BAL) and open lung biopsy were performed in all patients to confirm the diagnosis. All patients had progressive dyspnea or exertional dyspnea. They had basal fine crakles on auscultation and predominantly peripheral, subpleural, bibasal fine reticular shadows and/or honeycombing, occasionally with traction bronchiectasis and bronchioloectasis on HRCT. There was no evidence of either a history of occupational dust exposure or $\mathrm{CO}-$ existing collagen - vascular disease in any of the patients. One hundred thirtyfour control subjects visited to Gachon University Gil Hospital for routine medical examination from 1 January 2000 to 30 July 2006. All control subjects was performed low dose chest computed tomography (CT). There was no evidence of lung disease on clinical history and low dose CT in control subjects. We analyzed medical records of IPF patients and control subjects, retrospectively, including sex, age, past history, smoking history, DM, hypertension, hyperlipidemia, laboratory data, pulmonary function test, body weight, height. If IPF patients had steroid therapy, the levels of factors were affected. Thus, We excluded IPF patients that had received steroid therapy.

The diagnosis of IPF is, corresponding to the international consensus statement of American Thoracic Society and European Respiratory Society 2002, as follows: (1) exclusion of other known causes of interstitial lung disease such as certain drug toxicities, environmental exposures, and connective tissue disease (2) abnormal pulmonary function studies that include evidence of restriction (3) bibasal reticular abnormalities with minimal ground glass opacities on HRCT (4) result of open lung biopsy was IPF, pathologically ${ }^{11}$.

The diagnosis of DM was established by satisfying one of the following criteria: (1) known DM patient with treatment including hypoglycemic agent, diet, exercise et al. (2) fasting glucose $\geq 126 \mathrm{mg} / \mathrm{dL}$ and/or $\mathrm{HbA}_{1 \mathrm{C}}>6.0 \%{ }^{12}$. The hypertension was diagnosed by satisfying one of the following criteria: (1) Known hypertension patients with treatment including antihypertensive agent, diet, exercise et al. (2) Systolic blood pressure $\geq 140 \mathrm{mmHg}$, or diastolic blood pressure $\geq 90 \mathrm{mmHg}$ based on The Seventh Report of the Joint National Committee ${ }^{13}$. Obesity was considered when body mass index (BMI) was $\geq 25^{14}$. The diagnosis of hyperlipidemia was established by satisfying one of the following criteria: (1) Known hyperlipidemia with treatment with any medication for hyperlipidemia (2) Total cholesterol $\geq 200 \mathrm{mg} / \mathrm{dL}$ and/or triglyceride $\geq 150 \mathrm{mg} / \mathrm{dL}$ and/or LDL cholesterol $\geq 100 \mathrm{mg} / \mathrm{dL}$ based on Adult Treatment Panel III classification ${ }^{15}$. The definition of smoker was current smoker and non-smoker (cessation of less than1 year). The non-smoker was associated with never smoker and ex-smoker (cessation of over 1 year). The study was approved by the Institutional Research Board of Gachon University Gil Hospital for human study.

\section{Statistical analysis}

Data were expressed mean \pm standard deviation. Continuous data were done by the Student t-test and categorical data were compared by the Pearson's chi-square test. Multiple logistic regression analysis was performed 
to assess the role of several variables as risk factors for the IPF. Differences were considered significant when the $\mathrm{p}$ value was less than 0.05 . Statistical analyzed were performed by version 13.0 of SPSS for Windows (SPSS, Inc., Chicago, IL, USA).

\section{Results}

\section{Clinical characteristics, blood tests and pulmonary function tests between two groups}

One hundred fourteen patients with IPF and 134 control subjects were enrolled. About $70 \%$ of both IPF patients and control subjects were male (69.3\% and 70.9\%).
The mean age of each group was 60.1 \pm 7.9 years in IPF patients and $59.8 \pm 4.5$ years in control subjects. The two groups have no significant difference in other clinical features; smoking history (18.8 \pm 25.4 pack-year vs. $19.4 \pm$ 21.2 pack-year), body weight $(63.4 \pm 13.7 \mathrm{~kg}$ vs. $59.5 \pm$

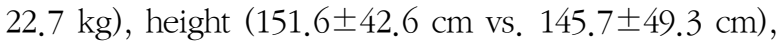
BMI $\left(22.9 \pm 6.9 \mathrm{~kg} / \mathrm{m}^{2}\right.$ vs. $\left.21.9 \pm 7.8 \mathrm{~kg} / \mathrm{m}^{2}\right)$, systolic

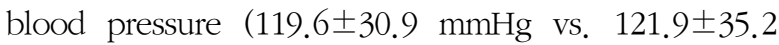
$\mathrm{mmHg})$, diastolic blood pressure $(74.1 \pm 18.3 \mathrm{mmHg}$ vs. $75.2 \pm 21.7 \mathrm{mmHg})$. The level of serum fasting glucose was significantly higher $(114.3 \pm 61.1 \mathrm{mg} / \mathrm{dL})$ in IPF patients than in control subjects $(99.8 \pm 34.7 \mathrm{mg} / \mathrm{dL})$. IPF patients have significantly high level of total white blood

Table 1. Comparison of clinical characteristics, blood tests and pulmonary function tests between patients with IPF and control subjects

\begin{tabular}{|c|c|c|c|}
\hline Characteristics & Patients with IPF $(n=114)$ & Control subjects $(n=134)$ & p-value \\
\hline Age (yr) & $60.1 \pm 7.9$ & $59.8 \pm 4.5$ & 0.780 \\
\hline Sex (M/F) (\% of male) & $79: 35$ (69.3) & $95: 39(70.9)$ & 0.785 \\
\hline Smoking (pack-year) & $18.8 \pm 25.4$ & $19.4 \pm 21.2$ & 0.832 \\
\hline Body weight (kg) & $63.4 \pm 13.7$ & $59.5 \pm 22.7$ & 0.103 \\
\hline Height $(\mathrm{cm})$ & $151.6 \pm 42.6$ & $145.7 \pm 49.3$ & 0.318 \\
\hline $\mathrm{BMI}\left(\mathrm{kg} / \mathrm{m}^{2}\right)$ & $22.9 \pm 6.9$ & $21.9 \pm 7.8$ & 0.316 \\
\hline Systolic blood pressure $(\mathrm{mmHg})$ & $119.6 \pm 30.9$ & $121.9 \pm 35.2$ & 0.587 \\
\hline Diastolic blood pressure (mmHg) & $74.1 \pm 18.3$ & $75.2 \pm 21.7$ & 0.667 \\
\hline \multicolumn{4}{|l|}{ Laboratory finding } \\
\hline $\mathrm{Hb}(\mathrm{g} / \mathrm{dL})$ & $13.5 \pm 2.4$ & $13.8 \pm 3.3$ & 0.438 \\
\hline $\mathrm{WBC}(/ \mu \mathrm{L})$ & $8,060.4 \pm 2,948.2$ & $6,277.3 \pm 2,488.2$ & 0.000 \\
\hline Segment neutrophil (\%) & $59.8 \pm 40.4$ & $51.0 \pm 15.5$ & 0.021 \\
\hline Lymphocyte (\%) & $31.8 \pm 11.3$ & $32.3 \pm 10$ & 0.706 \\
\hline Eosinophil (\%) & $3.4 \pm 2.4$ & $3.4 \pm 2.5$ & 0.849 \\
\hline Platelet $(/ \mu \mathrm{L})$ & $170.2 \pm 119.7$ & $247.4 \pm 95.7$ & 0.000 \\
\hline $\mathrm{ESR}(\mathrm{mm} / \mathrm{h})$ & $31.6 \pm 40.4$ & $9.9 \pm 11.8$ & 0.000 \\
\hline LDH (IU/L) & $271.7 \pm 228.0$ & $286.0 \pm 146.6$ & 0.568 \\
\hline Glucose (mg/dL) & $114.3 \pm 61.1$ & $99.8 \pm 34.7$ & 0.026 \\
\hline T-chol (mg/dL) ${ }^{\star}$ & $154.2 \pm 76.3$ & $177.8 \pm 7.3$ & 0.010 \\
\hline $\mathrm{TG}(\mathrm{mg} / \mathrm{dL})^{\dagger}$ & $78.9 \pm 115.5$ & $135.5 \pm 106.7$ & 0.000 \\
\hline $\mathrm{HDL}(\mathrm{mg} / \mathrm{dL})$ & $20.1 \pm 23.0$ & $45.0 \pm 21.0$ & 0.000 \\
\hline LDL (mg/dL) & $53.1 \pm 62.4$ & $103.2 \pm 48.8$ & 0.000 \\
\hline Protein (g/dL) & $7.0 \pm 1.1$ & $6.7 \pm 1.7$ & 0.214 \\
\hline Albumin (g/dL) & $3.8 \pm 0.7$ & $4.1 \pm 1.0$ & 0.006 \\
\hline \multicolumn{4}{|l|}{ Pulmonary function test } \\
\hline $\mathrm{FEV}_{1}(\%)$ & $71.4 \pm 38.2$ & $85.7 \pm 49.4$ & 0.011 \\
\hline FVC (L) & $2.3 \pm 1.3$ & $2.7 \pm 1.5$ & 0.070 \\
\hline FVC (\%) & $63.4 \pm 34.0$ & $80.6 \pm 45.1$ & 0.001 \\
\hline $\mathrm{FEV}_{1} / \mathrm{FVC}(\%)$ & $67.8 \pm 31.1$ & $71.2 \pm 32.5$ & 0.398 \\
\hline
\end{tabular}

IPF: idiopathic pulmonary fibrosis.

${ }^{\star}$ Total cholesterol, ${ }^{\dagger}$ Triglyceride. 
YJ Kim et al: Diabetes mellitus and metabolic syndrome in IPF

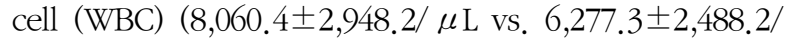
$\mu \mathrm{L})$, segmented neutrophil $(59.8 \pm 40.4 \%$ vs. $51.0 \pm$

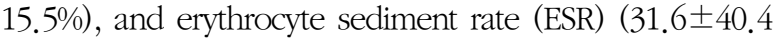
$\mathrm{mm} / \mathrm{h}$ vs. $9.9 \pm 11.8 \mathrm{~mm} / \mathrm{h})$. Total cholesterol, triglyceride, HDL cholesterol and LDL cholesterol were lower in IPF patients than in control subjects (154.2 \pm 76.3 $\mathrm{mg} / \mathrm{dL}$ vs. $177.8 \pm 7.3 \mathrm{mg} / \mathrm{dL} ; 78.9 \pm 115.5 \mathrm{mg} / \mathrm{dL}$ vs. $135.5 \pm 106.7 \mathrm{mg} / \mathrm{dL} ; 20.1 \pm 23.0 \mathrm{mg} / \mathrm{dL}$ vs. $45.0 \pm 21.0$ $\mathrm{mg} / \mathrm{dL} ; 53.1 \pm 62.4 \mathrm{mg} / \mathrm{dL}$ vs. $103.2 \pm 48.8 \mathrm{mg} / \mathrm{dL})$ respectively. The level of $\mathrm{FEV}_{1}(\mathrm{~L}), \mathrm{FEV}_{1}(\%)$, and FVC (\%)

Table 2. Risk factors for IPF in relation to metabolic disorders and smoking

\begin{tabular}{|c|c|c|c|c|c|c|c|}
\hline \multirow{2}{*}{ Risk factor } & IPF & Control & \multicolumn{2}{|c|}{ Unadjusted data } & \multicolumn{3}{|c|}{ Adjusted data ${ }^{\dagger}$} \\
\hline & \multicolumn{2}{|c|}{ n (\%) } & OR (95\% Cl) & $p$-value & OR & $(95 \% \mathrm{Cl})$ & $p$-value \\
\hline Smoking & $56(49.1)$ & $83(61.9)$ & $0.661(0.393 / 1.112)$ & 0.118 & 0.694 & $(0.395 / 1.219)$ & 0.204 \\
\hline Hypertension & $23(20.2)$ & $36(26.9)$ & $0.669(0.367 / 1.219)$ & 0.188 & 0.675 & $(0.352 / 1.294)$ & 0.236 \\
\hline $\mathrm{DM}^{*}$ & $29(25.4)$ & $18(13.4)$ & $2.199(1.146 / 4.217)$ & 0.016 & 2.733 & $(1.282 / 5.827)$ & 0.009 \\
\hline Obesity & $47(41.2)$ & $51(38.1)$ & $1.093(0.646 / 1.851)$ & 0.740 & 2.001 & $(1.063 / 3.766)$ & 0.040 \\
\hline Hyperlipidemia & $33(28.9)$ & $53(39.6)$ & $0.663(0.380 / 1.156)$ & 0.177 & 0.593 & $(0.326 / 1.078)$ & 0.086 \\
\hline
\end{tabular}

IPF: idiopathic pulmonary fibrosis.

${ }^{*}$ Diabetes mellitus, ${ }^{\dagger}$ Adjusted for age, sex.

Table 3. Clinical characteristics, the results of blood and pulmonary function tests in IPF patients with or without diabetes mellitus

\begin{tabular}{|c|c|c|c|}
\hline Characteristics & With DM $(n=29)$ & Without DM (n=85) & $p$-value \\
\hline Age (yr) & $61.5 \pm 6.9$ & $59.8 \pm 8.1$ & 0.255 \\
\hline Pack-year (py) & $27.4 \pm 34.7$ & $15.8 \pm 20.8$ & 0.033 \\
\hline Body weight (kg) & $64.0 \pm 9.0$ & $63.1 \pm 15.0$ & 0.773 \\
\hline Height $(\mathrm{cm})$ & $163.4 \pm 7.5$ & $147.6 \pm 48.5$ & 0.005 \\
\hline $\mathrm{BMI}\left(\mathrm{kg} / \mathrm{m}^{2}\right)$ & $23.9 \pm 2.6$ & $22.5 \pm 7.8$ & 0.178 \\
\hline Systolic blood pressure (mmHg) & $124.5 \pm 17.2$ & $118.0 \pm 34.2$ & 0.329 \\
\hline Diastolic blood pressure (mmHg) & $75.9 \pm 9.6$ & $73.4 \pm 20.5$ & 0.536 \\
\hline \multicolumn{4}{|l|}{ Laboratory findings } \\
\hline $\mathrm{Hb}(\mathrm{g} / \mathrm{dL})$ & $13.7 \pm 1.8$ & $13.5 \pm 2.5$ & 0.706 \\
\hline WBC $(/ \mu \mathrm{L})$ & $8,522.1 \pm 3,047.0$ & $7,902.8 \pm 2,915.4$ & 0.331 \\
\hline Platelet $(/ \mu \mathrm{L})$ & $122.2 \pm 112.7$ & $186.8 \pm 118.2$ & 0.012 \\
\hline ESR (mg/dL) & $29.7 \pm 28.9$ & $32.3 \pm 43.8$ & 0.765 \\
\hline LDH (IU/L) & $270.2 \pm 187.9$ & $272.3 \pm 240.7$ & 0.967 \\
\hline Glucose (mg/dL) & $113.0 \pm 64.5$ & $114.8 \pm 60.3$ & 0.890 \\
\hline T-chol $(\mathrm{mg} / \mathrm{dL})^{\star}$ & $171.3 \pm 79.9$ & $148.3 \pm 74.6$ & 0.163 \\
\hline $\mathrm{TG}(\mathrm{mg} / \mathrm{dL})^{\dagger}$ & $125.7 \pm 135.9$ & $62.9 \pm 103.9$ & 0.011 \\
\hline $\mathrm{HDL}(\mathrm{mg} / \mathrm{dL})$ & $32.2 \pm 22.0$ & $16.0 \pm 21.9$ & 0.001 \\
\hline $\mathrm{LDL}(\mathrm{mg} / \mathrm{dL})$ & $84.8 \pm 64.6$ & $42.3 \pm 58.1$ & 0.001 \\
\hline Protein (g/dL) & $7.0 \pm 0.4$ & $6.9 \pm 1.2$ & 0.617 \\
\hline Albumin (g/dL) & $3.8 \pm 0.5$ & $3.8 \pm 0.73$ & 0.695 \\
\hline \multicolumn{4}{|l|}{ Pulmonary function test } \\
\hline $\mathrm{FEV}_{1}(\%)$ & $77.4 \pm 34.8$ & $69.4 \pm 39.3$ & 0.332 \\
\hline FVC (L) & $2.7 \pm 1.0$ & $2.2 \pm 1.35$ & 0.114 \\
\hline FVC (\%) & $68.4 \pm 31.8$ & $61.7 \pm 34.8$ & 0.365 \\
\hline $\mathrm{FEV}_{1} /$ FVC (\%) & $79.7 \pm 17.2$ & $63.8 \pm 33.8$ & 0.001 \\
\hline
\end{tabular}

IPF: idiopathic pulmonary fibrosis.

${ }^{\star}$ Total cholesterol, ${ }^{\dagger}$ Triglyceride. 
Tuberculosis and Respiratory Diseases Vol. 67. No. 2, Aug. 2009

Table 4. Clinical characteristics, the results of blood and pulmonary function tests in IPF patients with or without obesity

\begin{tabular}{|c|c|c|c|}
\hline Characteristics & With obesity $(n=47)$ & Without obesity (n=59) & p-value \\
\hline Age (yr) & $58.5 \pm 8.6$ & $60.8 \pm 7.5$ & 0.137 \\
\hline Pack-year (py) & $18.7 \pm 21.6$ & $20.6 \pm 28.9$ & 0.707 \\
\hline Body weight (kg) & $70.3 \pm 7.9$ & $60.7 \pm 7.1$ & 0.000 \\
\hline Height (cm) & $162.3 \pm 8.2$ & $160.8 \pm 22.7$ & 0.671 \\
\hline BMI $\left(\mathrm{kg} / \mathrm{m}^{2}\right)$ & $27.0 \pm 2.2$ & $22.7 \pm 1.9$ & 0.000 \\
\hline Systolic blood pressure (mmHg) & $126.9 \pm 25.9$ & $117.5 \pm 27.8$ & 0.077 \\
\hline Diastolic blood pressure (mmHg) & $78.0 \pm 14.8$ & $73.2 \pm 16.5$ & 0.120 \\
\hline \multicolumn{4}{|l|}{ Laboratory finding } \\
\hline $\mathrm{Hb}(\mathrm{g} / \mathrm{dll})$ & $13.6 \pm 2.6$ & $13.5 \pm 1.4$ & 0.686 \\
\hline WBC $(/ \mu \mathrm{L})$ & $7,746.4 \pm 2,061.2$ & $8,101.2 \pm 2,826.3$ & 0.472 \\
\hline Platelet $(/ \mu \mathrm{L})$ & $174.5 \pm 124.1$ & $163.4 \pm 116.4$ & 0.640 \\
\hline ESR (mg/dL) & $34.7 \pm 53.2$ & $30.6 \pm 9.5$ & 0.620 \\
\hline LDH (IU/L) & $263.7 \pm 242.8$ & $255.8 \pm 191.7$ & 0.853 \\
\hline Glucose (mg/dL) & $130.2 \pm 75.7$ & $106.1 \pm 46.6$ & 0.047 \\
\hline T-chol (mg/dL)* & $160.0 \pm 5.7$ & $156.7 \pm 74.0$ & 0.825 \\
\hline $\mathrm{TG}(\mathrm{mg} / \mathrm{dL})^{\dagger}$ & $81.3 \pm 115.4$ & $75.1 \pm 108.7$ & 0.774 \\
\hline $\mathrm{HDL}(\mathrm{mg} / \mathrm{dL})$ & $20.0 \pm 22.0$ & $21.4 \pm 24.0$ & 0.758 \\
\hline LDL (mg/dL) & $55.5 \pm 63.8$ & $56.9 \pm 62.9$ & 0.910 \\
\hline Protein (g/dL) & $7.1 \pm 0.5$ & $6.9 \pm 1.1$ & 0.226 \\
\hline Albumin (g/dL) & $3.9 \pm 0.4$ & $3.8 \pm 0.7$ & 0.112 \\
\hline \multicolumn{4}{|l|}{ Pulmonary function test } \\
\hline $\mathrm{FEV}_{1}(\mathrm{~L})$ & $1.8 \pm 1.0$ & $2.0 \pm 1.0$ & 0.258 \\
\hline $\mathrm{FEV}_{1}(\%)$ & $68.7 \pm 34.5$ & $76.8 \pm 38.2$ & 0.260 \\
\hline FVC (L) & $2.3 \pm 1.3$ & $2.5 \pm 1.2$ & 0.455 \\
\hline FVC (\%) & $62.7 \pm 32.2$ & $66.9 \pm 33.1$ & 0.515 \\
\hline $\mathrm{FEV}_{1} / \mathrm{FVC}(\%)$ & $66.4 \pm 31.0$ & $72.7 \pm 27.8$ & 0.273 \\
\hline
\end{tabular}

IPF: idiopathic pulmonary fibrosis.

${ }^{\star}$ Total cholesterol, ${ }^{\dagger}$ Triglyceride.

in IPF patients was significantly lower than in control

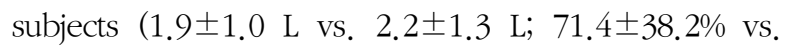
$85.7 \pm 49.4 \% ; 63.4 \pm 34.0 \%$ vs. $80.6 \pm 45.1 \%)$ respectively (Table 1).

\section{Association of metabolic disorders with IPF}

Univariate analysis was performed to evaluate nonadjusted odds ratio about risk factor between IPF patients and control subjects. Odds ratio (OR) of DM was statistically different between IPF patients and control subjects. OR of DM was 2.199 (95\% CI, 1.146 4.217, $\mathrm{p}=0.016)$. The prevalence of $\mathrm{DM}$ was $25.4 \%(\mathrm{n}=25)$ for IPF and $13.4 \%(n=18)$ for control subjects. The OR of other factors were not significant different; obesity, 1.093; smoking status, 0.661; hypertension, 0.669; hyperlipidemia, 0.663 (Table 2). We analyzed each risk factor by multivariate analysis in which DM and obesity were significantly associated with IPF. The adjusted OR of DM and obesity was 2.733 (95\% CI, 1.282 5.827) and 2.001 (95\% CI, 1.063 3.766). The adjusted OR of smoking status was 0.694 (95\% CI, $0.395 \sim 1.219)$. Hypertension (adjusted OR, 0.675; 95\% CI, 0.352 1.294) and hyperlipidemia (adjusted OR, 0.593; 95\% CI, $0.326 \sim 1.078$ ) were not statistically significant (Table 2 ).

\section{Differences between IPF patients with DM or with- out DM, and patients with obesity or without ob- esity}

We analyzed IPF patients with DM or without (Table 3). Smoking history, height, triglyceride, HDL, LDL, $\mathrm{FEV}_{1}$ and $\mathrm{FEV}_{1} / \mathrm{FVC}$ were significantly higher in IPF patients with DM than in IPF without DM. We also eval- 
uated IPF patients with obesity or without obesity (Table 4). Glucose were significantly higher in IPF patients with obesity.

\section{Discussion}

We showed that the prevalence of DM in IPF patients was significantly higher than in control subjects $(25.4 \%$ vs. 13.4\%). The level of fasting glucose in IPF patients was also significantly higher than in control subjects (114.3 $\pm 61.1 \mathrm{mg} / \mathrm{dL}$ vs. $99.8 \pm 34.7 \mathrm{mg} / \mathrm{dL})$, and the adjusted OR of DM by multivariate analysis was 2.733 (95\% CI, 1.282 5.827). These results supported a previous report that the prevalence of DM was higher in patients with IPF than in control subjects ${ }^{4}$. On the other hand, there was a conflicting report that DM was not associated with $\mathrm{IPF}^{3}$. In that report, investigators had collected data by self-administered questionnaires and defined individuals who were only being in dietary or drug treatment as DM patients. They did not include latent or untreated DM. So they might have underestimated true association ${ }^{3}$. In this current study, obesity (OR 2.001) is also significantly associated with IPF using multivariate analysis. As the prevalence of obesity is getting increased in general, many investigators have been interested in chronic diseases which might be associated with obesity. Obesity was known to be one of important risk factors in the metabolic syndrome, and associated with an increased risk of DM and heart diseases $^{15,16}$. There have been conflict reports about relationship between obesity and $\mathrm{IPF}^{3,4}$. One had reported that BMI of IPF patients was higher than in control subject $^{3}$. On the contrary, the other investigation showed that BMI and obesity, which was defined as BMI of $>25$, were not related to IPF. They showed the prevalence of obesity was not statistically different between IPF patients and control subjects ${ }^{4}$. In our study, more patients were analyzed than in study of previous studies ${ }^{4}$. Accordingly our study might have stronger statistical power than previous studies ${ }^{4}$. Although definition of obesity in metabolic syndrome has been identified as abdominal obesity $^{17}$, we used BMI as a parameter for obesity.
There are some reports that measurement of BMI as well as waist circumference has been used to identify insulin resistance and cardiovascular risk factors ${ }^{18,19}$. It is still cautious to analyze obesity-related data due to different definition of obesity. Hyperlipidemia and hypertension were not associated with IPF in this current study like previous studies. Smoking status was not significant related to the risk of IPF, which was inconsistent with previous investigations that smoking history was associated with an increased risk for the development of $\mathrm{IPF}^{3,4,20}$. Pack-years of smoking was not statistically associated with IPF in our study. Baumgartner et al. showed that current smoking and more than 40 pack-years of smoking in IPF patients were not significantly related to a risk of $\mathrm{IPF}^{3,20}$. Similar result was reported in the study of Yoshihiro et al. that there was no association with dose-response of cigarette smoking and IPF statistically ${ }^{3,20}$. We enrolled control subjects without lung diseases and abnormalities in low-dose CT. Because low-dose CT was performed to detect early lung cancer, most of control subjects had a smoking history so that smoking status was not so different from patients. It might be one reason that pack-years of smoking was not associated with IPF compared to control subjects in our study.

Recent studies have suggested that exogenous, endogenous multiple, microscopic stimuli may injure the alveolar epithelial cells, followed by an abnormal wound healing in the pathogenesis of $\mathrm{IPF}^{5-7}$. On the molecular level, a number of studies have reported that the imbalance of oxidants/antioxidants may play a significant role in the progression of pulmonary fibrosis ${ }^{1,2}$. The excess formation of reactive oxygen species (ROS) may cause tissue injuries including those involving the lung and leading to pulmonary fibrosis ${ }^{1,2,5-7}$. Many studies suggested that diabetes was involved by high level of free radicals or oxidant/antioxidant imbalance and oxidative stress may play a major role in the development and progression of DM and its complication ${ }^{8-10,21}$. Oxidative stress might be produced by advanced glycation end products (AGE) under hyperglycemia ${ }^{9,22}$. AGEs may inactivate enzymes and alter their structures and 
functions, promote free radical formation. AGEs may be linked to influence the expression of growth factors, cytokines and transcription factors that are believed in mediating the differentiation of epithelial cells to form myofibroblasts, such as TGF- $\beta 1$, CTGF and NF-k $\beta^{23-26}$. AGE may activate TGF- $\beta$-Smad signaling and influence mesangial cell hypertrophy and fibronectin synthesis ${ }^{22}$. AGEs can accumulate in alveolar macrophages and bronchial epithelial cells in idiopathic pulmonary fibrosis $^{27}$.

In the obese patients, adipose cells may play a role in endothelial dysfunction by pro-inflammatory cytokines, such as IL-6, TNF- $\alpha$. In cultured adipocytes, elevated levels of fatty acids increased oxidative stress via NADPH oxidase activation ${ }^{16}$.

The lung has developed antioxidant defense mechanism against oxidants ${ }^{1}$. This defense mechanism may be contributed to protect against pulmonary complication by oxidative stress and show less manifestation than other organs. Many results have reported that oxidative stress induced not only IPF but also DM, including obesity. The present study appears to support previous findings that DM may be associated with increased IPF. Moreover, our result provides an opportunity to raise interest about obesity as a risk factor of IPF. In conclusion, we demonstrate that DM and obesity are associated with IPF. Based on these results, we need to investigate more the relation between metabolic disorders such as DM, and obesity and IPF in perspective of molecular basis.

\section{Acknowledgements}

I would like to thank the authors in Gachon University Gil Hospital and Sungkyunkwan University Samsung Medical Center for help in recruiting patients and collecting data.

\section{References}

1. Kinnula VL, Fattman CL, Tan RJ, Oury TD. Oxidative stress in pulmonary fibrosis: a possible role for redox modulatory therapy. Am J Respir Crit Care Med 2005; 172:417-22.

2. Teramoto S, Fukuchi Y, Uejima Y, Shu CY, Orimo H. Superoxide anion formation and glutathione metabolism of blood in patients with idiopathic pulmonary fibrosis. Biochem Mol Med 1995;55:66-70.

3. Miyake Y, Sasaki S, Yokoyama T, Chida K, Azuma A, Suda T, et al. Case-control study of medical history and idiopathic pulmonary fibrosis in Japan. Respirology 2005;10:504-9.

4. Enomoto T, Usuki J, Azuma A, Nakagawa T, Kudoh $\mathrm{S}$. Diabetes mellitus may increase risk for idiopathic pulmonary fibrosis. Chest 2003;123:2007-11.

5. Selman M, King TE, Pardo A. Idiopathic pulmonary fibrosis: prevailing and evolving hypotheses about its pathogenesis and implications for therapy. Ann Intern Med 2001;134:136-51.

6. Kuwano K, Nakashima N, Inoshima I, Hagimoto N, Fujita M, Yoshimi M, et al. Oxidative stress in lung epithelial cells from patients with idiopathic interstitial pneumonia. Eur Respir J 2003;21:232-40.

7. Kim DS. Idiopathic pulmonary fibrosis and pulmonary fibrosis associated with collagen vascular diseases: clinical features, broncholaveolar lavage fluid findings and response to treatment. Korean J Med 1988;35:87-99.

8. Baynes JW, Thorpe SR. Role of oxidative stress in diabetic complications: a new perspective on an old paradigm. Diabetes 1999; 48:1-9.

9. Maritim AC, Sanders RA, Watkins JB 3rd. Diabetes, oxidative stress, and antioxidants: a review. J Biochem Mol Toxicol 2003;17:24-38.

10. Yu T, Robotham JL, Yoon Y. Increased production of reactive oxygen species in hyperglycemic conditions requires dynamic change of mitochondrial morphology. Proc Natl Acad Sci U S A 2006;103:2653-8.

11. American Thoracic Society. Idiopathic pulmonary fibrosis: diagnosis and treatment. International consensus statement. American Thoracic Society (ATS), and the European Respiratory Society (ERS). Am J Respir Crit Care Med 2000;161:646-64.

12. Expert Committee on the Diagnosis and Classification of Diabetes Mellitus. Report of the expert committee on the diagnosis and classification of diabetes mellitus. Diabetes Care 2003;26 Suppl 1:S5-20.

13. Chobanian AV, Bakris GL, Black HR, Cushman WC, Green LA, Izzo JL Jr, et al. The Seventh Report of the Joint National Committee on Prevention, Detection, Evaluation, and Treatment of High Blood Pressure: the JNC 7 report. JAMA 2003;289:2560-72. 
14. WHO Expert Consultation. Appropriate body-mass index for Asian populations and its implications for policy and intervention strategies. Lancet 2004;363:157-63.

15. National Cholesterol Education Program (NCEP) Expert Panel on Detection, Evaluation, and Treatment of High Blood Cholesterol in Adults (Adult Treatment Panel III). Third Report of the National Cholesterol Education Program (NCEP) Expert Panel on Detection, Evaluation, and Treatment of High Blood Cholesterol in Adults (Adult Treatment Panel III) final report. Circulation 2002;106:3143-421.

16. Furukawa S, Fujita T, Shimabukuro M, Iwaki M, Yamada Y, Nakajima Y, et al. Increased oxidative stress in obesity and its impact on metabolic syndrome. J Clin Invest 2004;114:1752-61.

17. Grundy SM, Brewer HB Jr, Cleeman JI, Smith SC Jr, Lenfant C; American Heart Association; National Heart, Lung, and Blood Institute. Definition of metabolic syndrome: Report of the National Heart, Lung, and Blood Institute/American Heart Association conference on scientific issues related to definition. Circulation 2004;109: 433-8.

18. Farin HM, Abbasi F, Reaven GM. Comparison of body mass index versus waist circumference with the metabolic changes that increase the risk of cardiovascular disease in insulin-resistant individuals. Am J Cardiol 2006;98:1053-6.

19. Sung KC, Ryu S, Reaven GM; Health Screening Group at Kangbuk Samsung Hospital. Relationship between obesity and several cardiovascular disease risk factors in apparently healthy Korean individuals: comparison of body mass index and waist circumference. Metabolism 2007; 56:297-303.

20. Baumgartner KB, Samet JM, Stidley CA, Colby TV, Waldron JA. Cigarette smoking: a risk factor for idio- pathic pulmonary fibrosis. Am J Respir Crit Care Med 1997;155:242-8.

21. Choi SB, Choi EK, Ann SH, Choi MK, Park SM. The effect of continuous subcutaneous insulin infusion therapy on oxidative stress in Korean type 2 diabetic patients. Korean J Med 2000;58:548-59.

22. Fukami K, Ueda S, Yamagishi S, Kato S, Inagaki Y, Takeuchi M, et al. AGEs activate mesangial TGF-beta-Smad signaling via an angiotensin II type I receptor interaction. Kidney Int 2004;66:2137-47.

23. Li JH, Wang W, Huang XR, Oldfield M, Schmidt AM, Cooper ME, et al. Advanced glycation end products induce tubular epithelial-myofibroblast transition through the RAGE-ERK1/2 MAP kinase signaling pathway. Am J Pathol 2004;164:1389-97.

24. Oldfield MD, Bach LA, Forbes JM, Nikolic-Paterson D, McRobert A, Thallas V, et al. Advanced glycation end products causes epithelial-myofibroblast transdifferentiation via the receptor for advanced glycation end products (RAGE). J Clin Invest 2001;108:1853-63.

25. Lee CI, Guh JY, Chen HC, Hung WC, Yang YL, Chuang LY. Advanced glycation end-product-induced mitogenesis and collagen production are dependent on angiotensin II and connective tissue growth factor in NRK49F cells. J Cell Biochem 2005;95:281-92.

26. Zhou G, Li C, Cai L. Advanced glycation end-products induce connective tissue growth factor-mediated renal fibrosis predominantly through transforming growth factor beta independent pathway. Am J Pathol 2004; 165:2033-43.

27. Matsuse T, Ohga E, Teramoto S, Fukayama M, Nagai $\mathrm{R}$, Horiuchi $\mathrm{S}$, et al. Immunohistochemical localisation of advanced glycation end products in pulmonary fibrosis. J Clin Pathol 1998;51:515-9. 